\title{
A CULTURA NA TRILHA dOS GUAIANÁS UMA INSPIRAÇÃO ETNOFOTOGRÁFICA NO CAMINHO DO OURO
}

\author{
Paulo Fernando Pires da Silveira ${ }^{1}$
}

A bela cidade de Paraty, no Estado do Rio de Janeiro, é geralmente conhecida pela Festa Literária Internacional de Paraty, pelo Festival Internacional de Fotografia e pelas imagens de seu centro histórico dialogando com a Serra do Mar. Antigo reduto de índios Guaianás, foi fundada no século XVI e vivenciou os ciclos ouro, café, cana e, hoje, o do turismo. Através da Carta Régia assinada por Dom Afonso VI, datada de 28 de Fevereiro de 1667, Paraty foi elevada da condição de povoado à de Vila, passando a ser denominada de Villa de Nossa Senhora dos Remédios de Paraty ${ }^{2}$. Segundo o Dossiê de $2007^{3}$ - O Caminho do Ouro em Paraty e sua Paisagem - redigido para obter a chancela de patrimônio junto à UNESCO, trata-se do município com “o mais íntegro conjunto arquitetônico brasileiro representativo da arquitetura dos séculos XVII ao XIX".

Antes da chegada da Coroa Portuguesa, os índios Guaianás ou Goiamimins alcançavam o vale do Rio Paraíba por meio de trilhas atravessando a Serra do Mar. Para eles, Paraty era um local de efeitos medicinais (Ribas, 2003). Estes indígenas, segundo o Dossiê de 2007, "habitaram a baía de Paraty até meados do século XVII". Este ensaio ${ }^{4}$ inspira-se na Etnofotografia proposta pelo arquiteto e fotógrafo italiano Sandro Spini e parte à (re)descoberta da chamada Trilha Guaianá que compõe a chamada Estrada Real ou Caminho do Ouro, cujo percurso atualmente 27 trechos do Sudeste brasileiro, destes trechos, destaco quatro: Ouro Preto (antiga Vila Rica) - São Bartolomeu, Tiradentes - São João del-Rei, São João del-Rei - São Sebastião da Vitória e Cunha - Paraty. (Re)descobrir a Trilha Guaianá significa explorar o imaginário das relações entre o passado e o presente das populações pré-colombianas e da colonização europeia; significa experimentar um percurso de ritmos e referências espaciais dissonantes com a experiência de vida moderna.

\footnotetext{
${ }^{1}$ Universidade La Salle, Brasil. Email: fernandopiresfotografia@gmail.com ORCID id: http://orcid.org/0000-0002-1892-0687

${ }^{2}$ Fonte: http://www.paratyonline.com/jornal/2012/02/confira-a-programacao-do-aniversario-de-paraty/ Acesso em: 22 nov. 2019.

${ }^{3}$ O Caminho do Ouro em Paraty e Sua Paisagem - A importância do reconhecimento de Paraty como Sítio do Patrimônio Mundial da UNESCO. - 11 de Setembro de 2007 - Prefeito Municipal: José Carlos Porto Neto.

${ }^{4}$ Este ensaio foi desenvolvido com a parceria/orientação do Prof. Dr. Lucas Graeff.
} 
Nômades por natureza, os primeiros habitantes do Brasil circulavam por uma vasta trama de trilhas que cortava o atual território brasileiro de ponta a ponta. Eram caminhos de caça, caminhos ligando aldeias e caminhos de migração, que mais tarde foram aproveitados pelos portugueses à medida que a colônia foi penetrando do litoral para o interior. (Ribas, 2003: 11).

Os três motivos principais destes movimentos de penetração eram "a busca de mão de obra escrava, o desejo de manter o gado longe das plantações de cana-de-açúcar do litoral e a procura por metais preciosos" (Ribas, 2003: 11). Destes movimentos, acredita-se que o mais importante, aquele que definitivamente mudou a cara do país "foi a corrida para o interior provocada pela descoberta do ouro no sertão dos Cataguás, no atual Estado de Minas Gerais" (Ribas, 2003: 11).

O Caminho do Ouro em Paraty, além de estar bastante preservado, se encontra envolto pela exuberância da Mata Atlântica do Parque Nacional da Serra da Bocaina, uma ecologia deslumbrante. A oportunidade de vivenciar este trecho do Caminho Velho é poder vivenciar os primeiros momentos da história da Villa de Nossa Senhora dos Remédios de Paraty, que por sua vez conta momentos importantes da história do Brasil: Ciclo do Ouro, Tráfico de índios e negros escravizados, Ciclo do Café e da Cana do Açúcar. Na época, no século 17, o percurso levava 60 dias para ser feito pelos tropeiros a cavalo.

Acredita-se que o nome Caminho do Ouro foi adotado em 19 de abril de 1702, após o Governador do Rio de Janeiro, Capitão-General Artur Sá de Menezes, baixar um novo Regimento das Minas, determinando que o ouro e as demais mercadorias teriam de obrigatoriamente entrar pelo caminho que passava por Paraty. A passagem que aproveitava a velha trilha dos Goianás já "aberta e descoberta” por Salvador Correa de Sá e Benevides ${ }^{5}$, por ser mais fechada e mais curta, era mais fácil de ser controlada. A estrada que passou a ser [re]construída (grifo meu), por índios e negros escravizados, a partir do século XVII, seguindo as trilhas dos índios guaianazes, tinha como ideia facilitar a ligação entre Minas Gerais, Rio de Janeiro e São Paulo, e acabou também aumentando o trânsito pelo Caminho do Ouro. A mudança fez com que Paraty, que exercia a função de Entreposto Comercial e por sua posição geográfica, transformou-se então também em uma das mais importantes cidades portuárias da colônia nos séculos XVII e XVIII, por escoar a produção de ouro de Minas para Portugal.

\footnotetext{
${ }^{5}$ Filho e neto de ex-governadores do Rio de Janeiro, era um dos homens mais importantes do Brasil no seu tempo. Fonte: RIBAS, Marcos Caetano. A história do caminho do ouro em Paraty. Contest Produções Culturais - Paraty / RJ, 2003.
} 
No entanto, durante todo este tempo existiram outros caminhos, trilhas e descaminhos:

As trilhas do mato não são como as modernas autoestradas de asfalto ou de cimento, fixas e imutáveis. São por sua natureza, incertas e movediças. Mesmo pelas trilhas principais, algumas veredas certamente teriam que existir para permitir a passagem furtiva dos famosos santos de pau oco, com ouro escondido no bojo, exemplos emblemáticos do contrabando generalizado que então se praticava. (Ribas, 2003: 14).

A Trilha ou "Caminho do Ouro foi classificado como patrimônio nacional em $1^{\circ}$ de Março de 1974, junto com todo Município” (Dossiê, 2007: 65). Ao longo de sua história já recebeu também outros nomes: Estrada da Serra do Facão, Estrada Geral da Serra do Mar, Caminho Velho, Caminho da Serra, Caminho Marítimo-Terrestre e Estrada Real ${ }^{6}$.

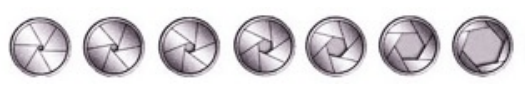

A saída a campo com inspiração etnofotográfica é um trabalho "que corresponde à valorização da imagem etnográfica como uma ferramenta que possui linguagem própria, e que utiliza dados da linguagem fotográfica para sustentar uma leitura antropológica" (Luisi, 1982: 153). Pois, a eficácia da fotografia

(...) reside na sua capacidade de recriar o seu objeto nos termos da realidade básica dele, e de se apresentar esta recriação de tal forma que o espectador sinta que está diante não apenas do símbolo daquele objeto, mas da própria essência da natureza dele revelada pela primeira vez. (Guran, 1992: 16).

É visível que o ato de fotografar - principalmente com câmeras profissionais - e de olhar e ver, se trata de "uma linguagem e de um processo de criação" ainda bastante obscuro para alguns pesquisadores, que requer estudo, atenção e planejamento, para não precisar retornar a campo mais vezes do que o planejado. No entanto,

a fotografia por ter se tornado uma atividade de massa, acabou tendo o "entendimento" de seu discurso e a consequente manipulação de sua linguagem listados no rol das coisas "simples", o que acarreta uma série de distorções [...]. (Guran, 1992: 17).

O período dos registros ${ }^{7}$ da narrativa fotográfica apresentada abaixo foi durante a 14 a edição do Paraty Em Foco 2018 - Festival Internacional de Fotografia. Em 2018,

\footnotetext{
${ }^{6}$ Em meados do século XVII, quando a Coroa Portuguesa decidiu oficializar os caminhos para o trânsito de ouro e diamantes de Minas Gerais até os portos do Rio de Janeiro. As trilhas que foram delegadas pela realeza ganharam o nome de Estrada Real. Fonte: http://www.institutoestradareal.com.br/estradareal Acesso em: 22 nov. 2019.

${ }^{7}$ Horário e duração da Saída a Campo: das 08:30 às 12:30.
} 
devido ao movimento turístico provocado pelo evento, que ocorre anualmente na cidade, a hospedagem só foi possível fora do Centro Histórico e a opção foi alugar pelo Airbnb, um quarto na Casa do Dharma ${ }^{8}$, situada do outro lado da cidade, após o Rio Perequê-Açu. O rio em questão, principal da região, faz uma segunda linha divisória de Paraty, onde ficam situados os bairros mais nobres: Pontal e Caborê, também conhecido como Beira-Rio, pois o Rio Perequê-Açú acompanha toda a sua extensão e confere ao local um charme todo especial. No início daquela manhã do dia 21 de setembro de 2018, antes de sair da Casa do Dharma, como parte do meu processo antes de uma Saída a Campo, já havia analisado a luz e a previsão meteorológica para o dia. $\mathrm{Na}$ mochila levei um pequeno mapa, meu moleskine e a minha câmera fotográfica, uma Nikon D610. Encontrei-me com o Guia de Turismo, Gabriel Toledo Pires, na outra margem do Rio Perequê-Açu, no início do Bairro Pontal. Partimos rumo à estrada Paraty - Cunha, e após alguns quilômetros o Gabriel deixou seu jeep estacionado próximo da Igreja da Nossa Senhora da Penha, para aguardamos um transporte público para continuar a subida até o ponto inicial da Trilha dos Guaianás.

Se entrar no Centro Histórico de Paraty é voltar aos séculos XVIII e XIX, entrar no Caminho do Ouro é voltar muito antes. O caminhar já não é mais obrigatoriamente sereno, pois as pedras pés-de-moleque estão em melhor estado do que as do Centro Histórico. Na medida que nos afastamos da estrada a mata vai se tornando mais densa e mais alta. Em muitos trechos da trilha se consegue visualizar durante a caminhada, que entre as pedras grandes e médias existem outras menores que ajudam no nivelamento da estrada, o que conferia mais sustentação ao caminhar dos tropeiros e das mulas daquela época. Literalmente, como diz o Guia Gabriel, “aqui é possível caminhar de olhos fechados". Na trilha, entre as pedras, com muita atenção, é possível avistar antigas ferraduras, indicando por ali um possível ponto de manutenção da tropa de animais" (Dossiê, 2007). Estes artefatos aguçam a imaginação e nos transportam para um outro século. No caminho é possível visualizar grandes pedras, algumas com um metro, outras com mais de um metro e meio de altura. Eram batizadas de pedras da vigia, por servirem de ponto de observação para um batedor armado que ia na frente da tropa e subia na pedra para avistar ao longe e assim evitar qualquer emboscada de saqueadores. Assim, a distância entre uma pedra da vigia e outra era relacionada com a distância que o projétil de uma arma de fogo quando disparada poderia atingir. Segundo a lenda,

\footnotetext{
${ }^{8}$ Casa do Dharma, espaço para meditação, yoga e Airbnb em Paraty/RJ.
} 
quando o Caminho faz uma curva bem encaixada entre duas grandes pedras, "o bandido Zé Migué, também conhecido como "Boca de Ouro", tocaiava as tropas, assustando a mula "madrinha" (líder) que dispersava as demais e facilitava a pilhagem" (Dossiê, 2007: 42).

Da mesma forma que a natureza é sábia para se auto reproduzir, na medida em que se lança à terra, por exemplo, as sementes da juçara, a palmeira que dá o açaí, mantem-se assim o ecossistema. E devido à alta declividade do terreno e às fortes chuvas, a natureza também provoca erosões criando diversos obstáculos para os novos viajantes, como árvores enraizadas por entre as pedras. Então, com "o objetivo de recomposição da cobertura florestal, bem como proporcionar sombra aos visitantes e garantir a estabilidade da encosta, em alguns locais do percurso a equipe do Projeto de Revitalização e os guias de turismo plantaram mudas de essências nativas (Dossiê, 2007: 65).

O Caminho do Ouro não era feito apenas de estradas com pedras enfileiradas, então em alguns trechos é possível encontrar intactas escadas construídas com pedras cortadas de forma retangular e/ou de troncos. Com o pouco fluxo de turistas, se comparado ao Centro Histórico, fungos das mais diversas espécies invadem a trilha. E o que a natureza produz, também sabiamente descarta, como os galhos da palmeira juçara, muito utilizados pelos indígenas e quilombolas para a confecção de artesanato (jogo americano, lustres, etc.). Além das 1328 espécies vegetais nessa região da Mata Atlântica, citadas no Dossiê de 2007, os enormes troncos caídos atestam a sua verdadeira dimensão no passado, no seu estado primário, apresentando diâmetros que não foram observados em outras árvores durante o Caminho percorrido.

Não podemos nos esquecer que todo o casario de Paraty, bem como suas igrejas, foram construídos com madeiras nobres, de grandes dimensões, retiradas justamente desta floresta, utilizadas como esteios, vigas, caibros, assoalhos e matéria prima para todo o mobiliário, bem como para as embarcações e canoas de voga, que chegavam a quase 2 metros de boca. (Dossiê, 2007: 64).

Se a flora é rica a fauna não fica muito atrás, se a trilha for realizada em silêncio e de forma contemplativa é possível avistar alguns sagüi-da-serra-escuro. Na verdade, segundo o Guia de Turismo, esta espécie não é de lá, então imagina-se que algum traficante de animais tenha libertado os primeiros na região; e como não havia um predador natural, acabaram se reproduzindo muito rápido, causando um desequilíbrio ecológico, pois se alimentam dos ovos de diversas espécies de aves da região. A título de informação, "na fauna terrestre - foram registradas 74 espécies de mamíferos, 345 de 
aves, 61 de répteis e anfíbios" em Paraty. (Dossiê, 2007: 220-221).

As grandes pedras cortadas encontradas pelo caminho sugerem um possível ponto de parada das tropas para manutenção dos animais e alimentação da própria tropa. Um outro personagem, não identificado, talvez um ouriço-cacheiro, espécie de mamífero da Mata Atlântica, foi avistado entre a vegetação, machucado e em possível fase terminal. Em longo percurso um dos poucos vestígios de civilização vistos foi uma cerca feita de troncos, sinalizando que ali próximo mora o seu Américo. "O seu Américo é o guardião do caminho, ele que está lá fazendo manutenção, limpando, fazendo o que precisa fazer pra gente poder passar com os visitantes" (Toledo, 2018). Com a contribuição da Associação de Guias de Turismo de Paraty, há uma manutenção constante, pois em alguns pontos da trilha, principalmente em ladeiras ou próximas de barranco, as fortes chuvas desorganizam a paisagem, mudam as pedras de lugar, fazem outras rolarem para a mata, o que torna o caminho mais difícil. Para compensar, em alguns trechos as pedras geometricamente alinhadas, embora cobertas de limo, parecem ter recebido manutenção recente. A floresta também se defende, sendo comum na trilha cruzar com espécies de vegetações que de longe parecem ser inofensivas, mas se raspar na pele humana gera uma ardência que faz pensar que trata-se de um corte profundo. Também é possível, em alguns pontos da trilha, avistar nascentes que além de mudarem a sonoridade da mata, oferecem uma água cristalina. 

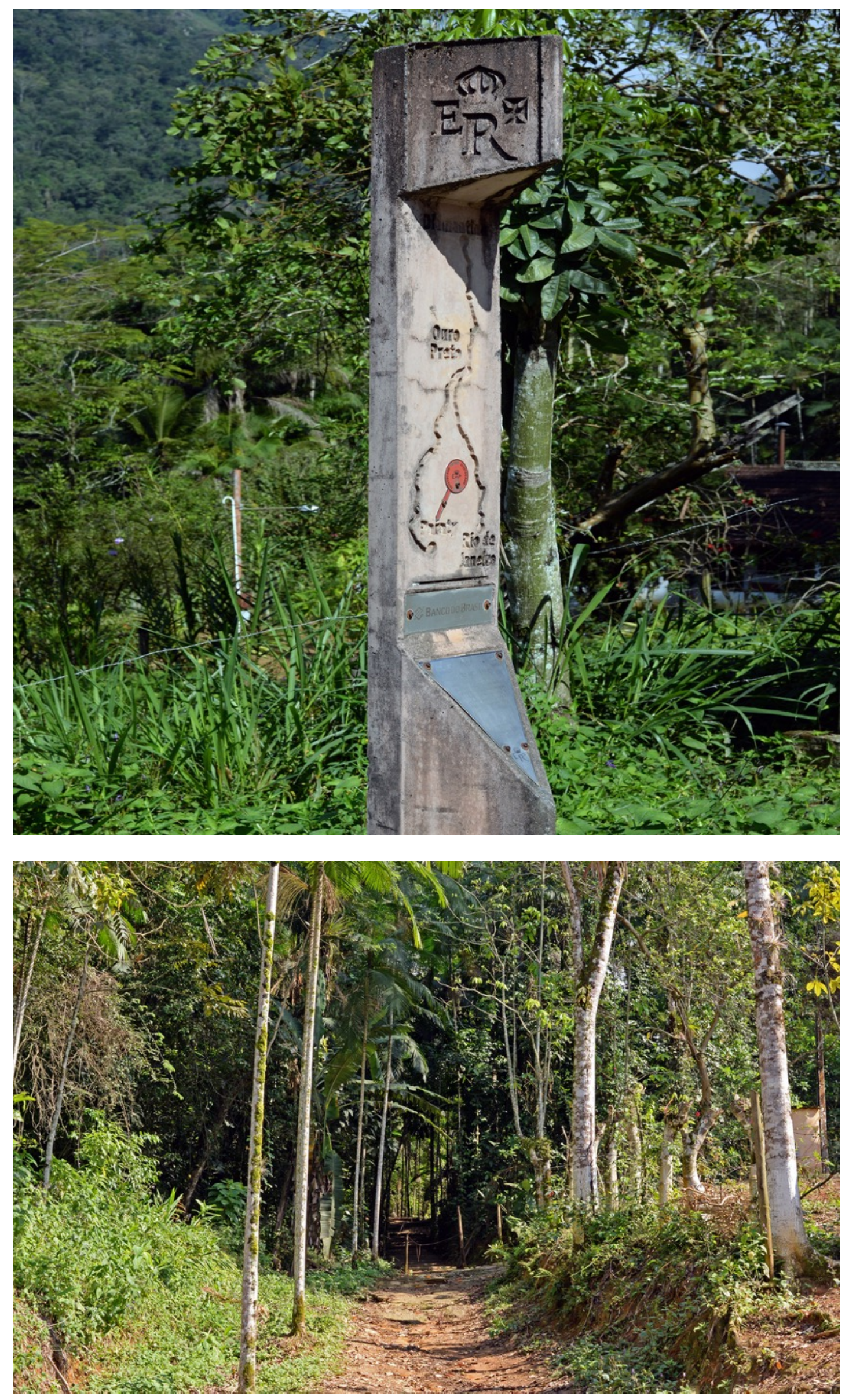

Iluminuras, Porto Alegre, v. 21, n. 55, p. 450-476, dezembro, 2020. 

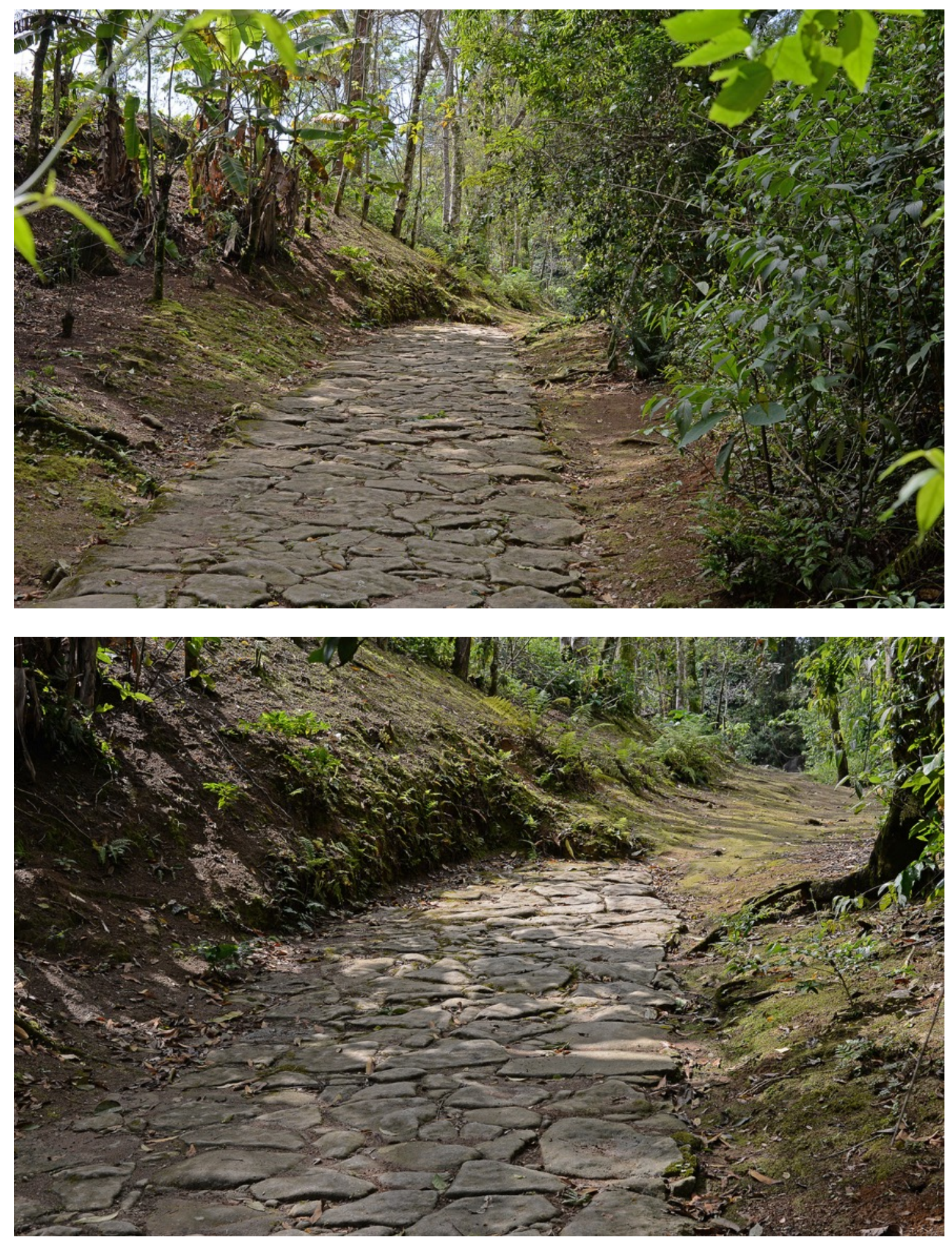

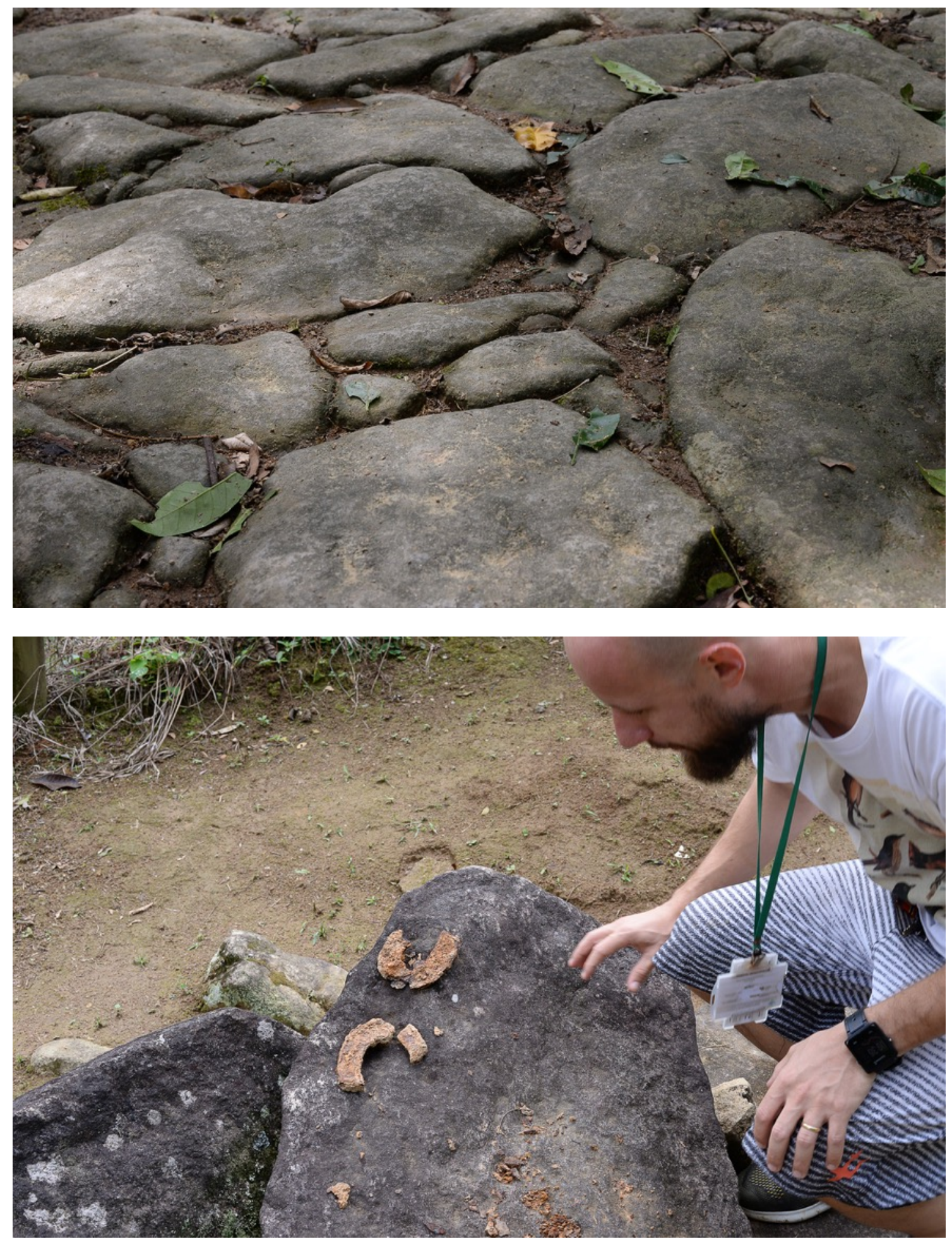

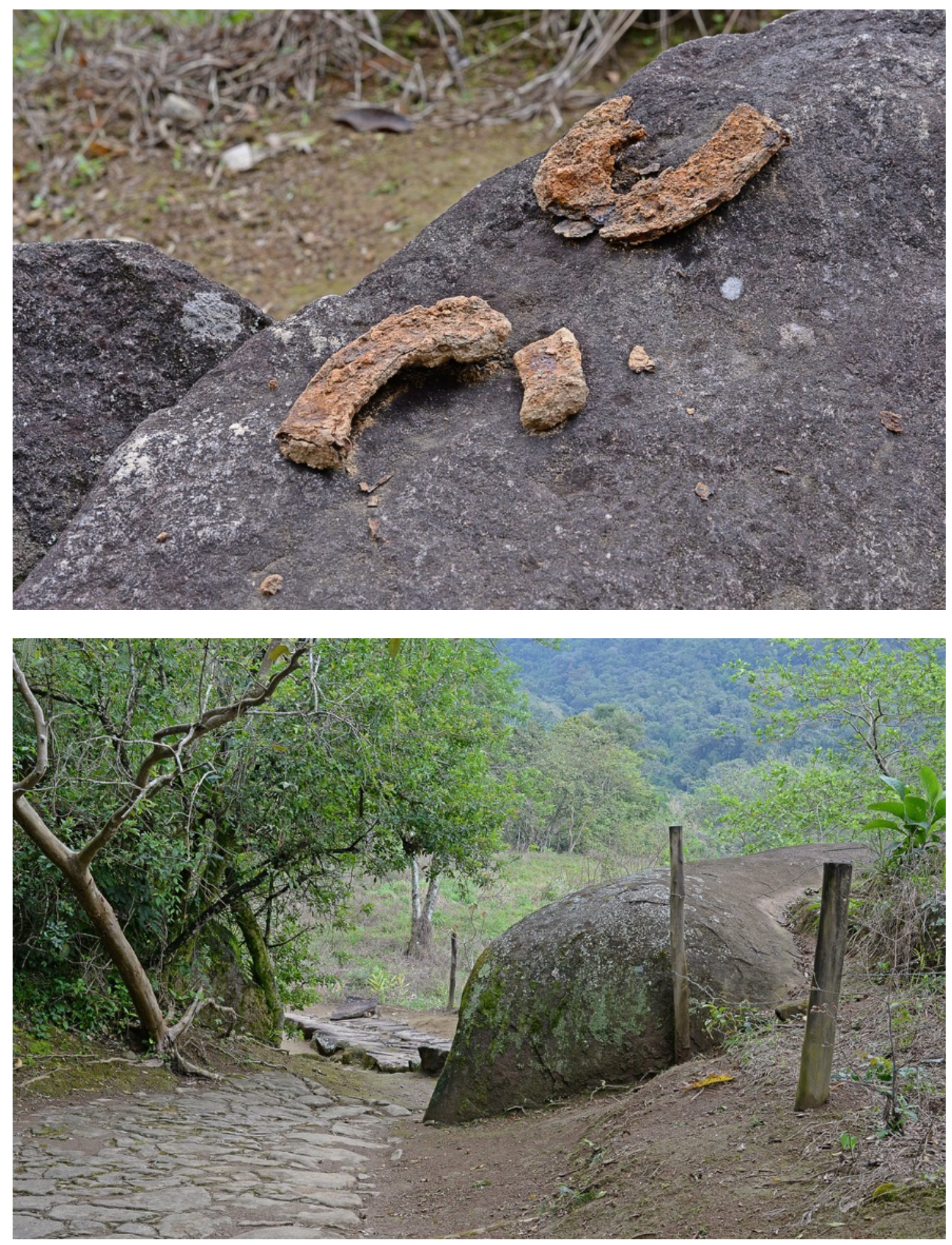

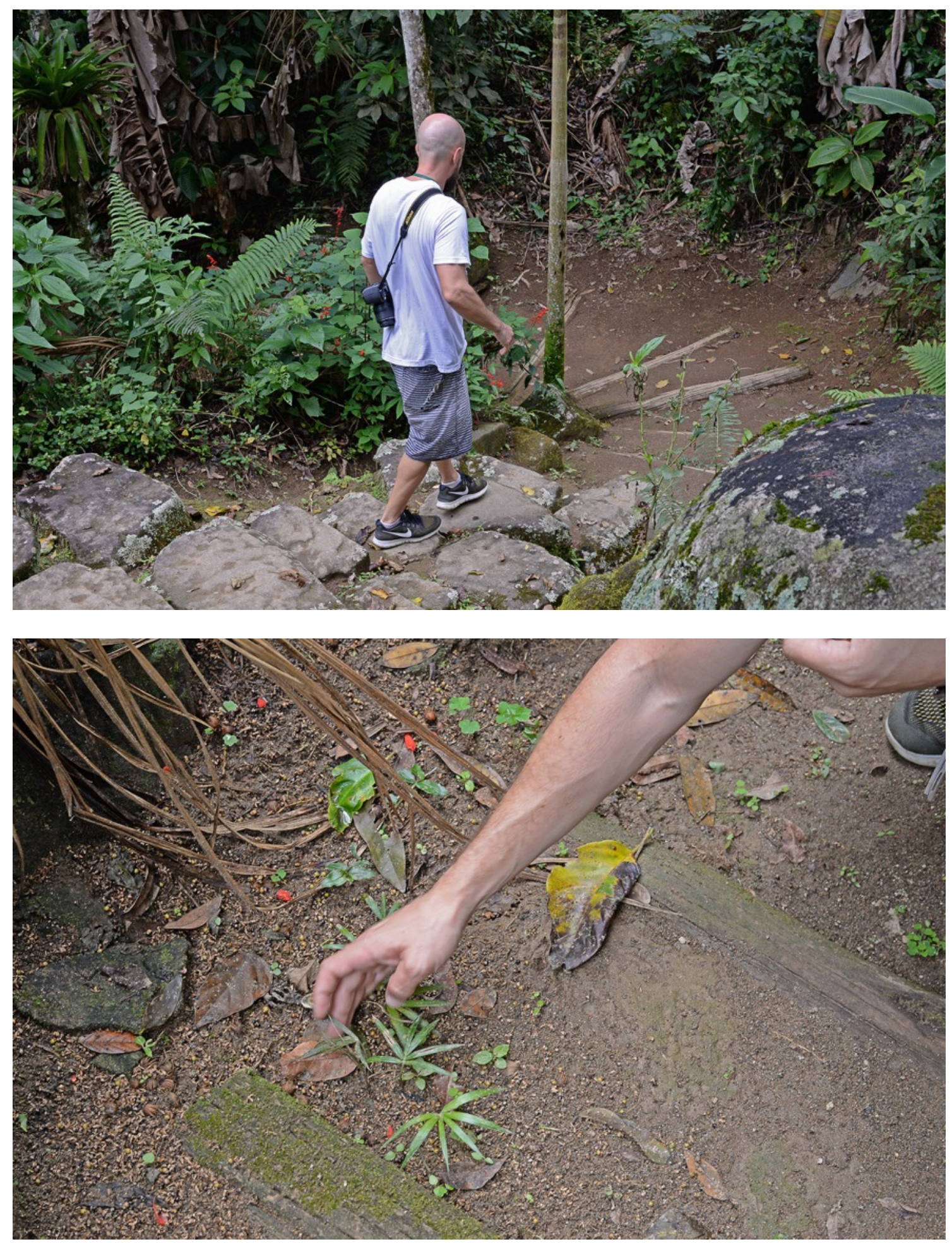

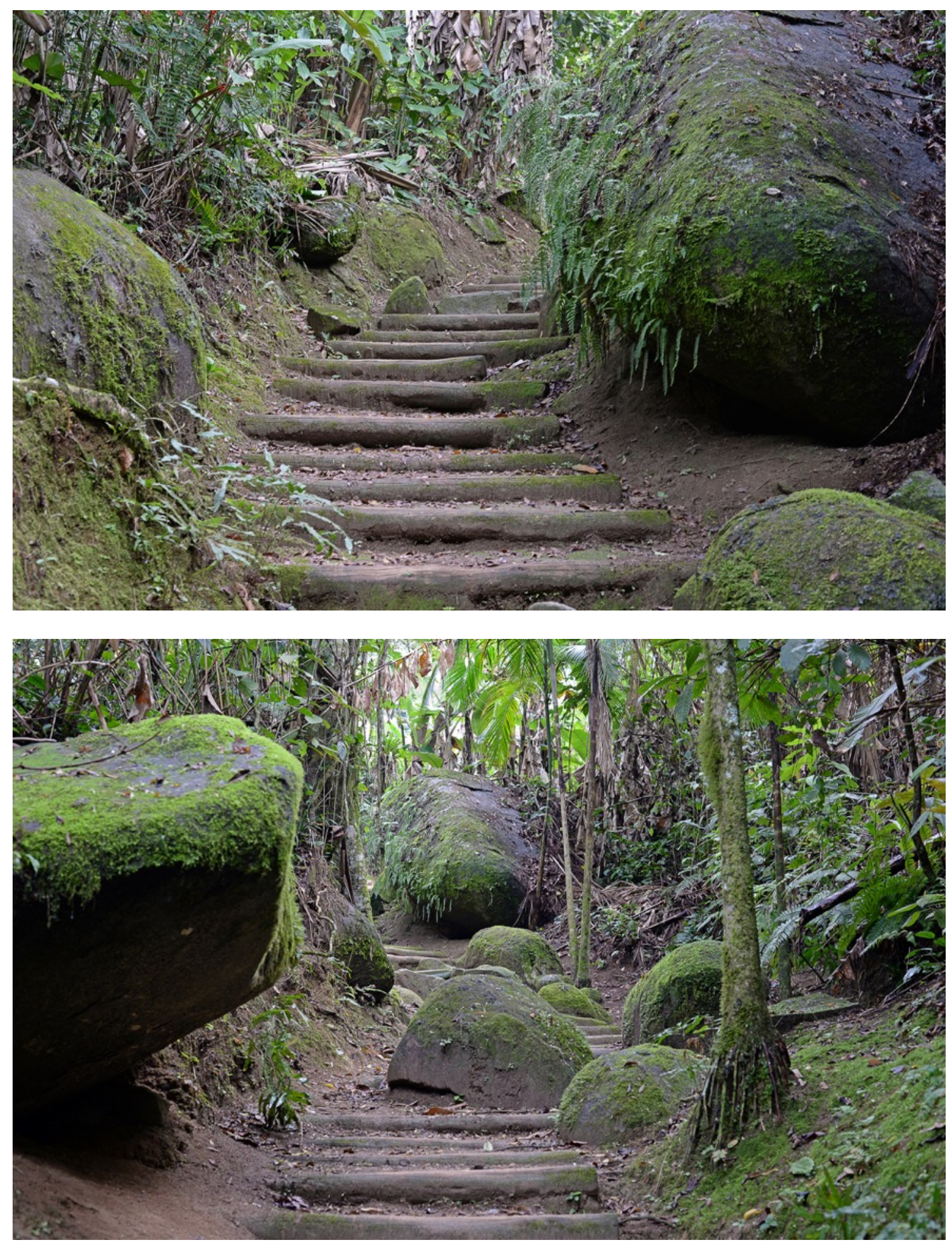

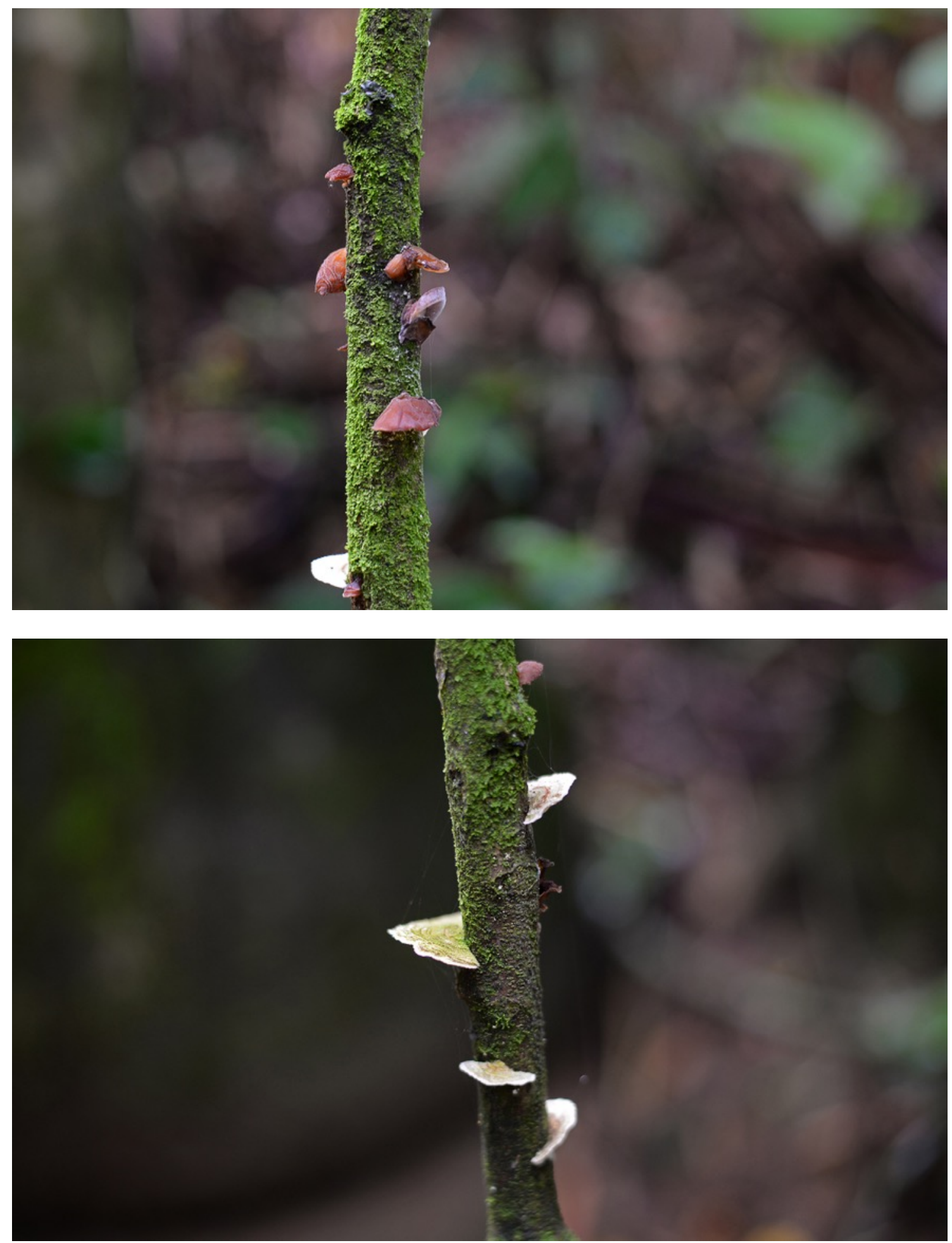

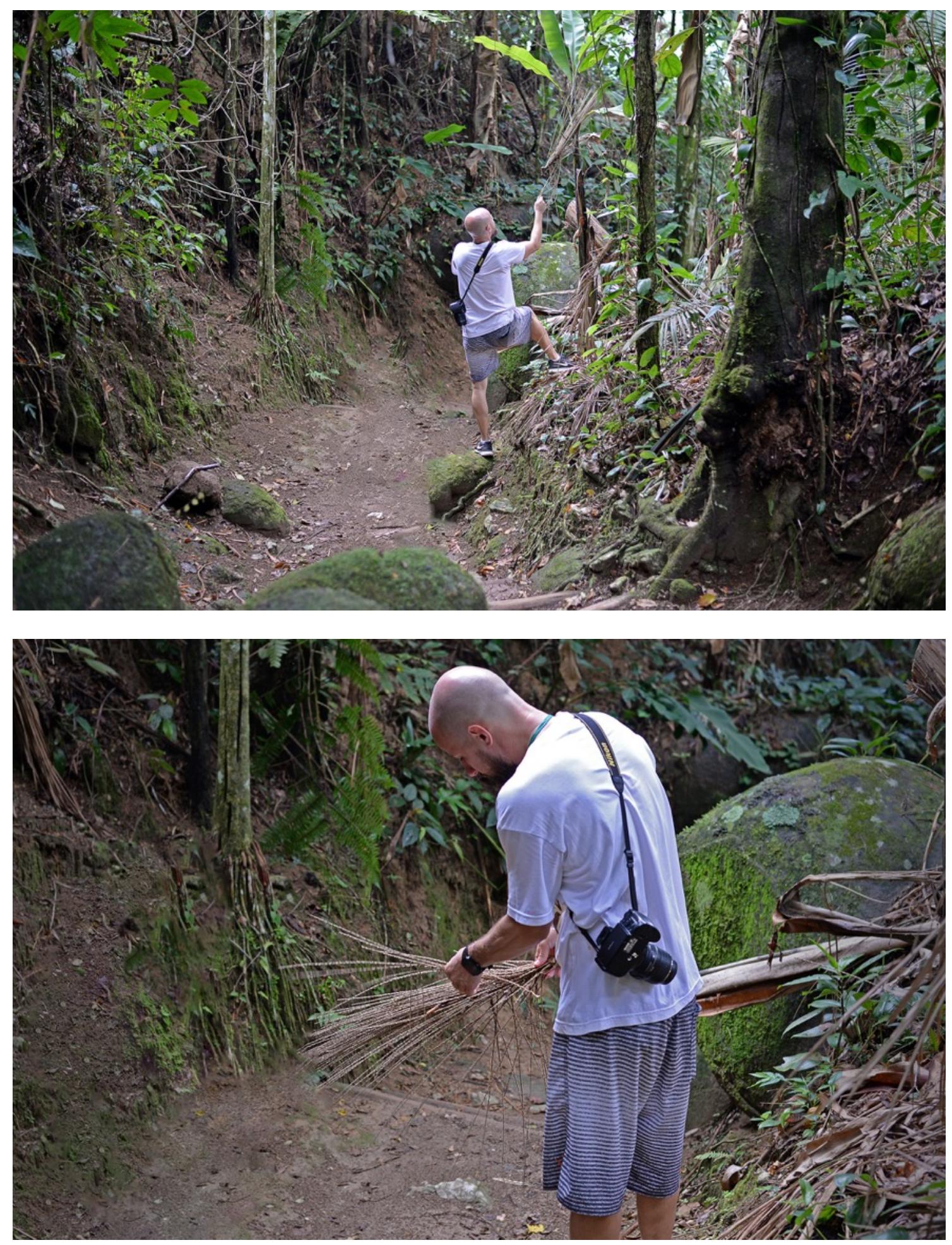

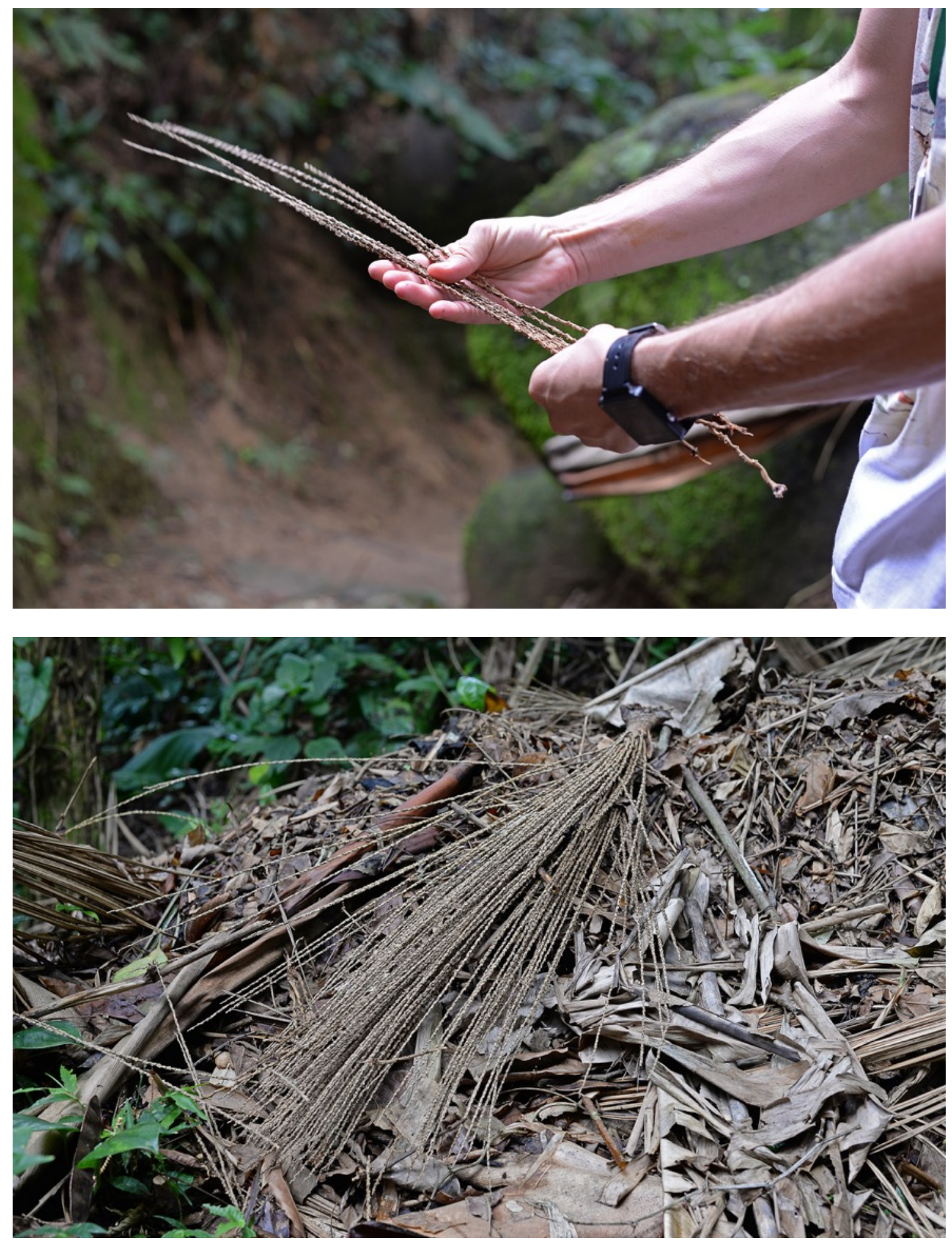

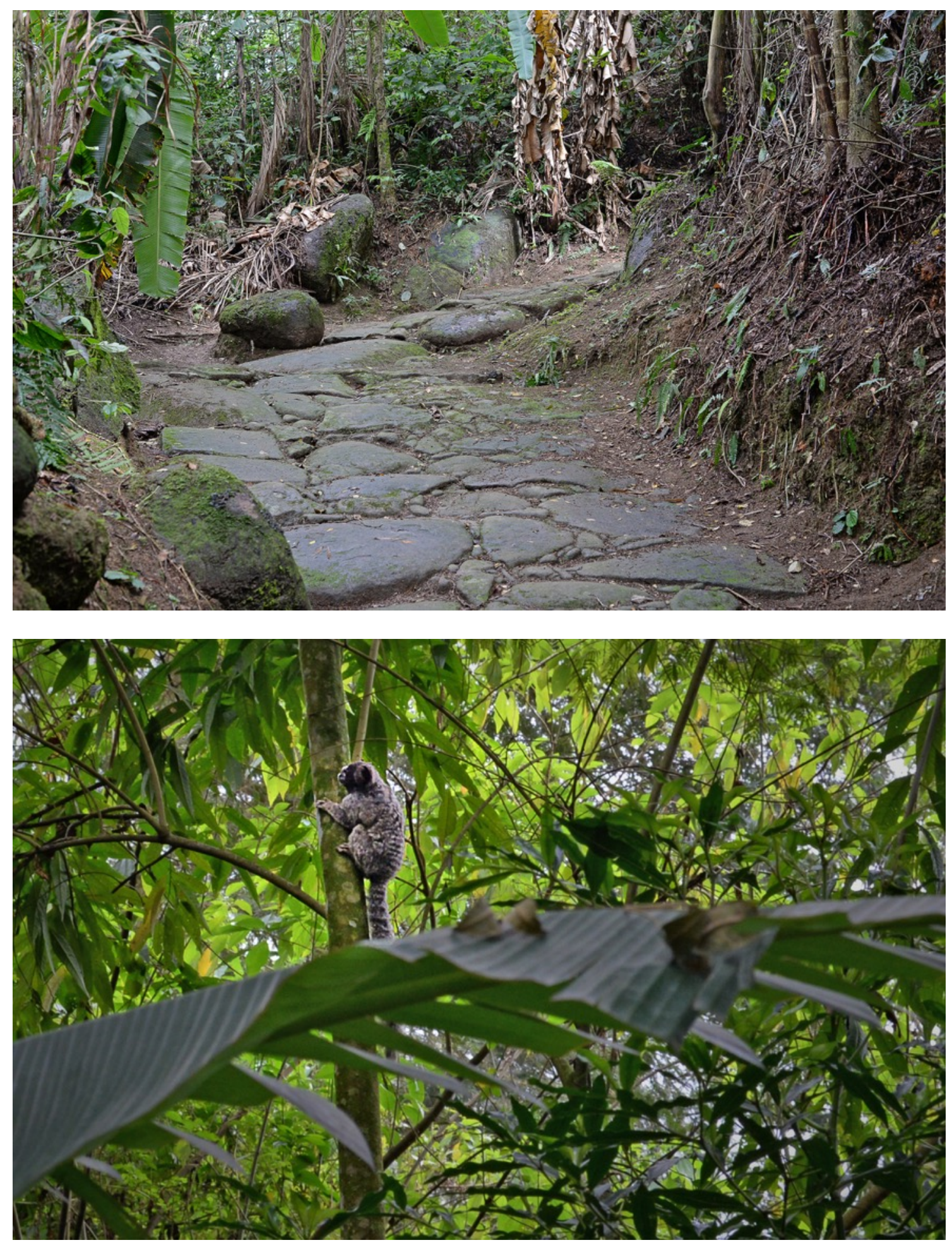

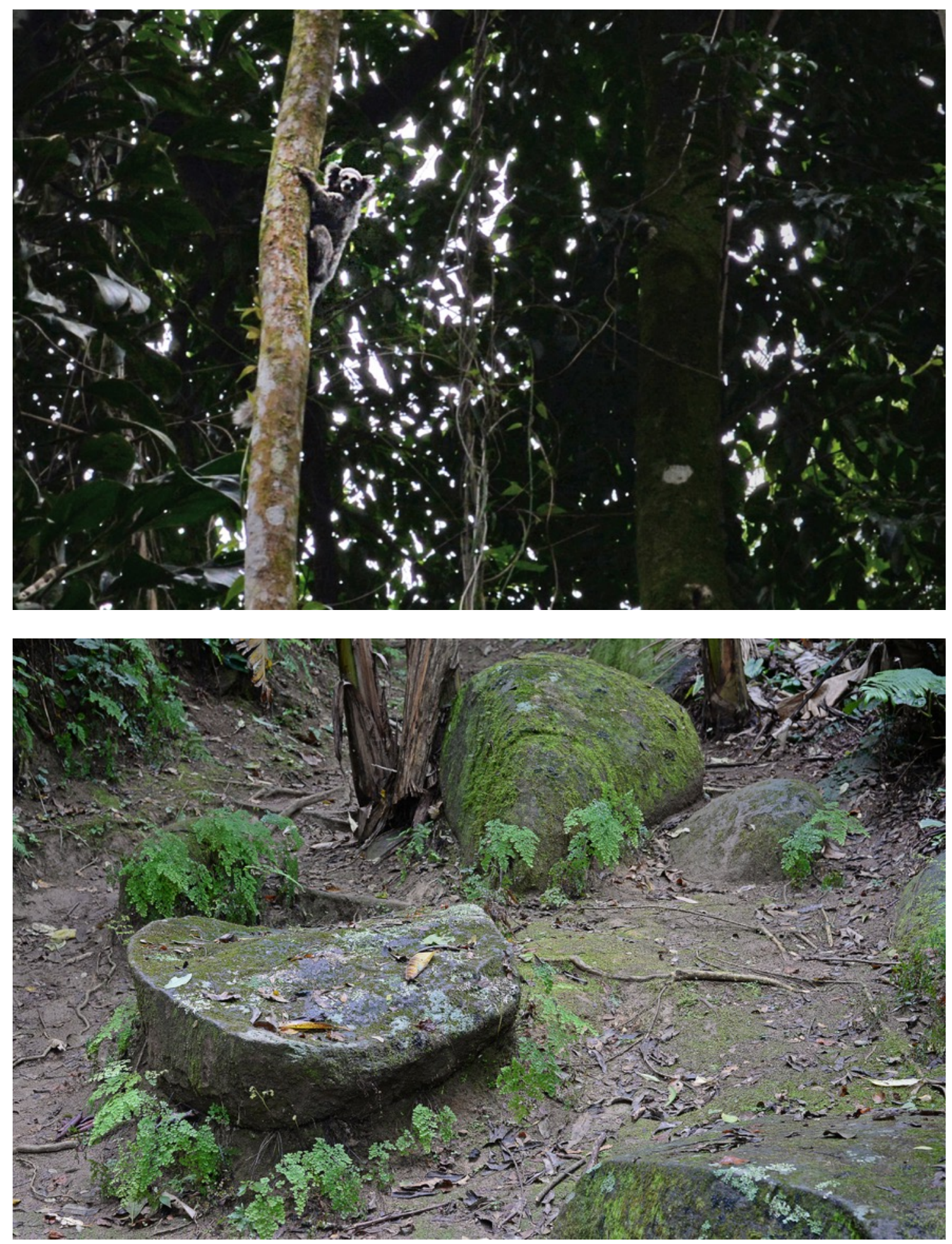

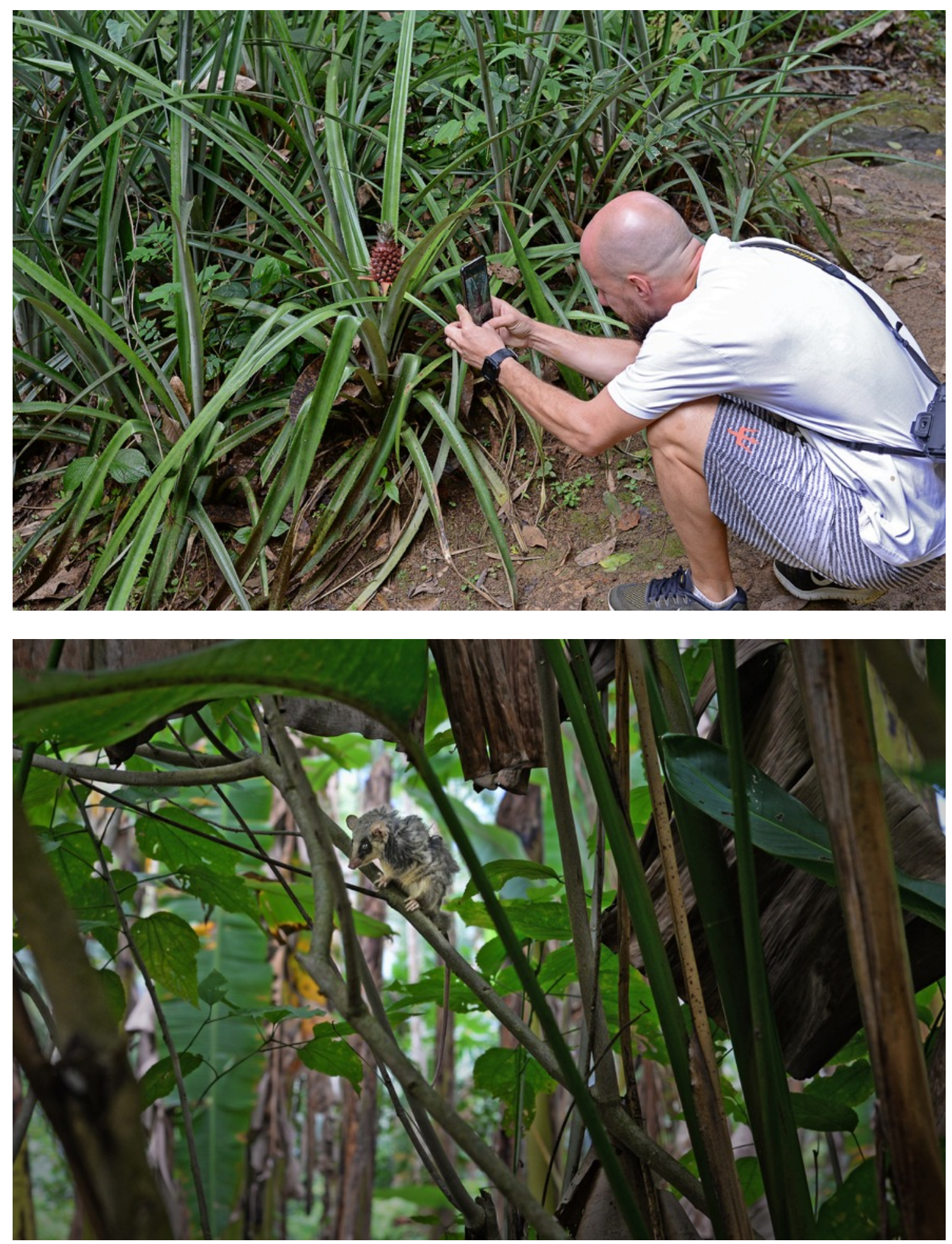

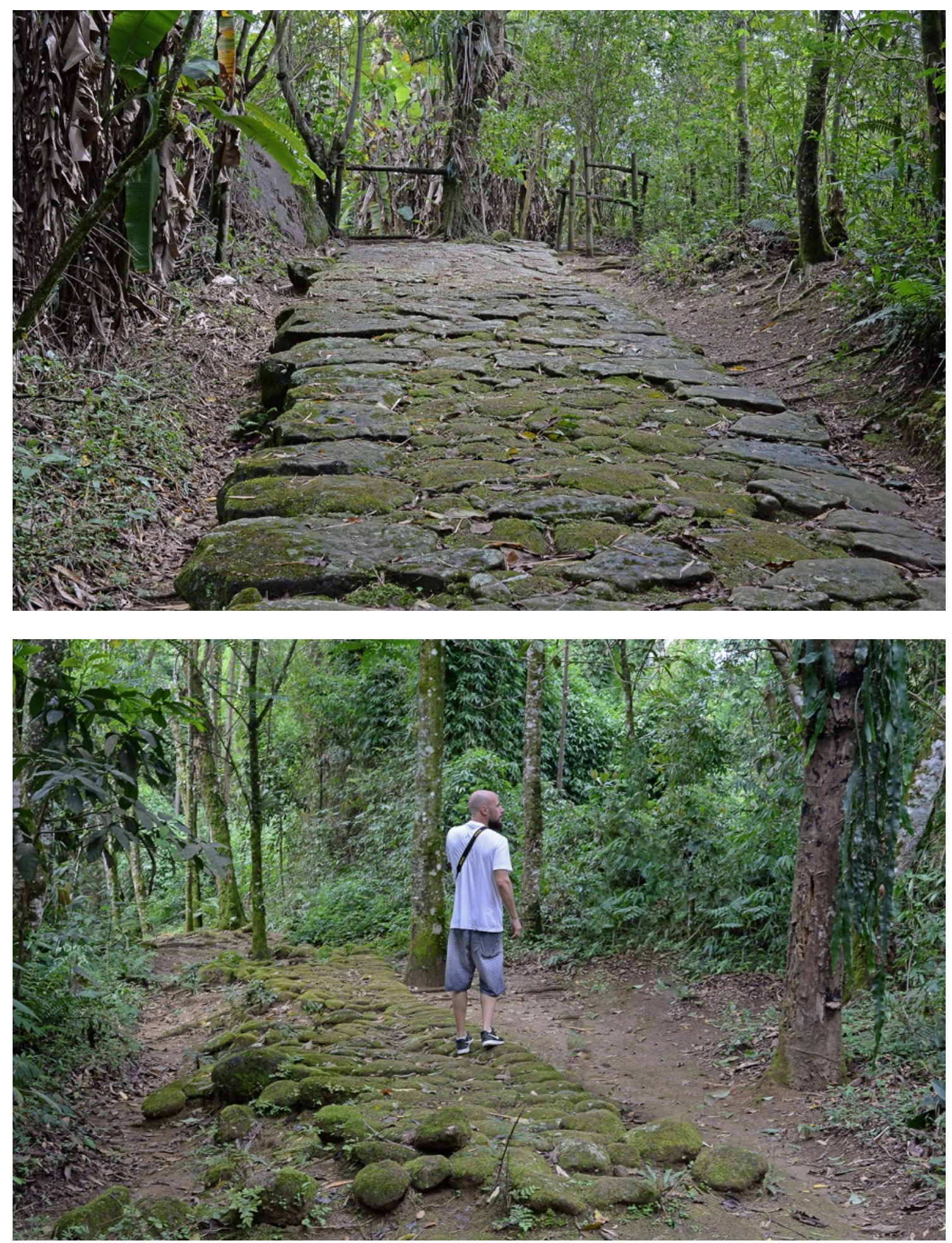

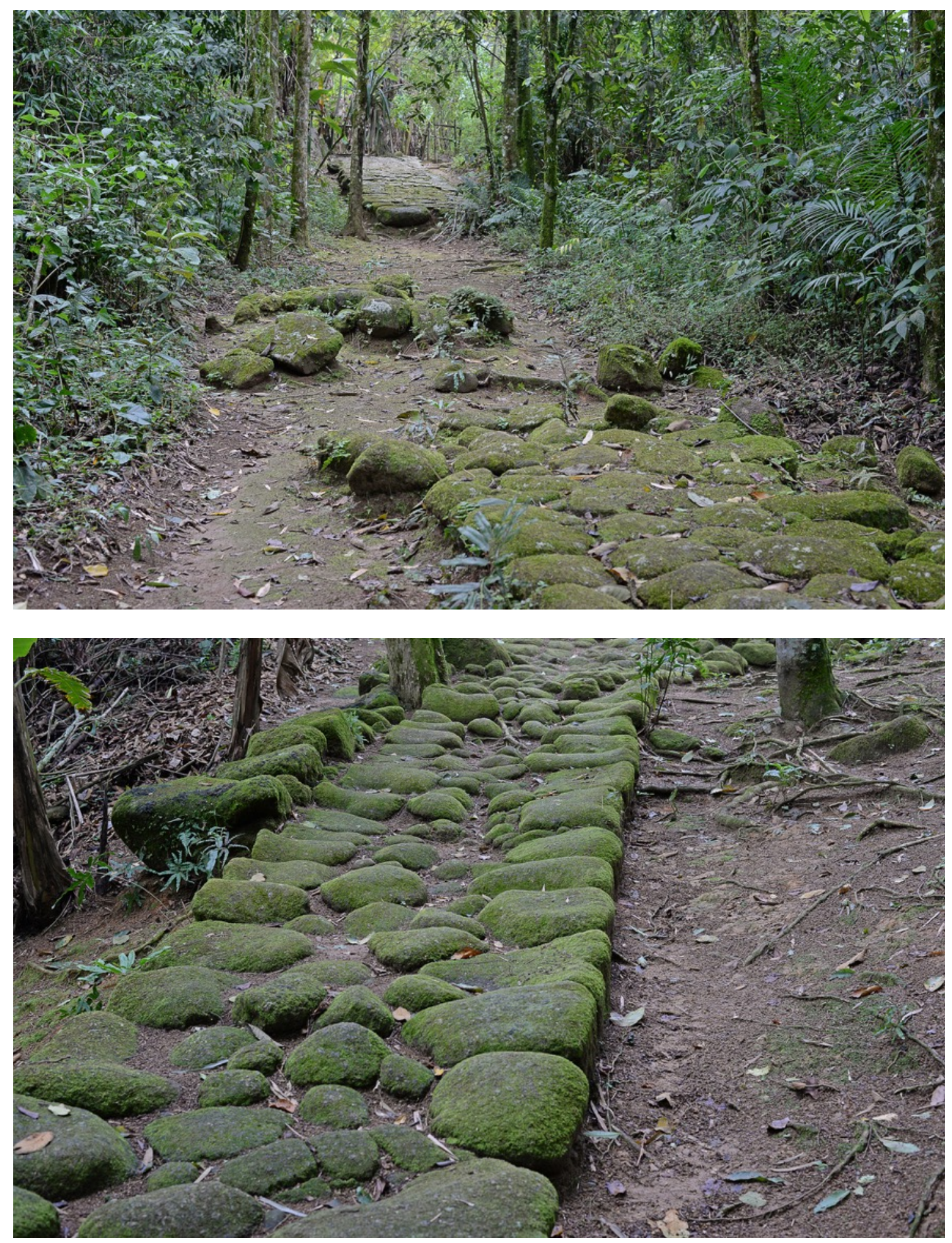

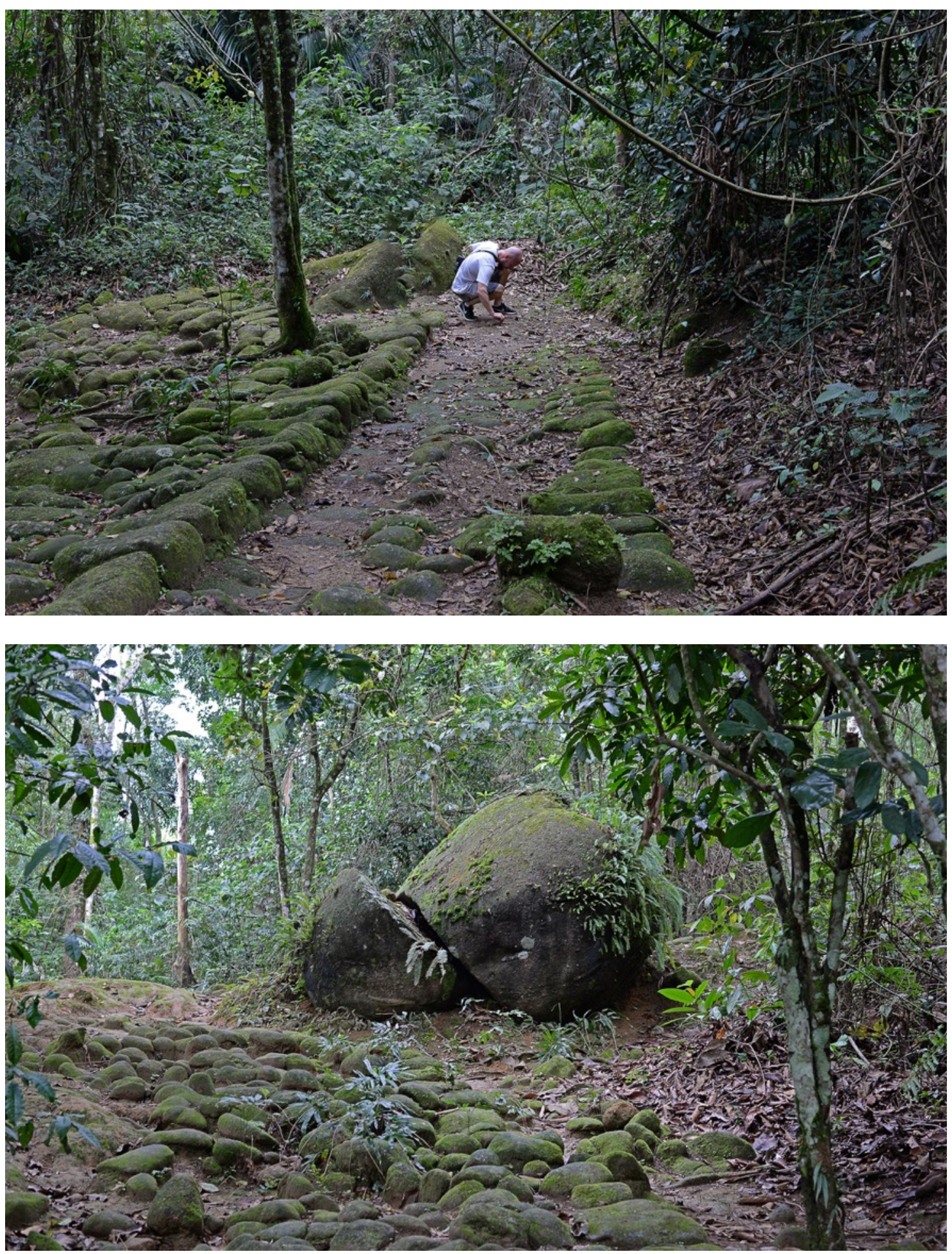

Iluminuras, Porto Alegre, v. 21, n. 55, p. 450-476, dezembro, 2020. 

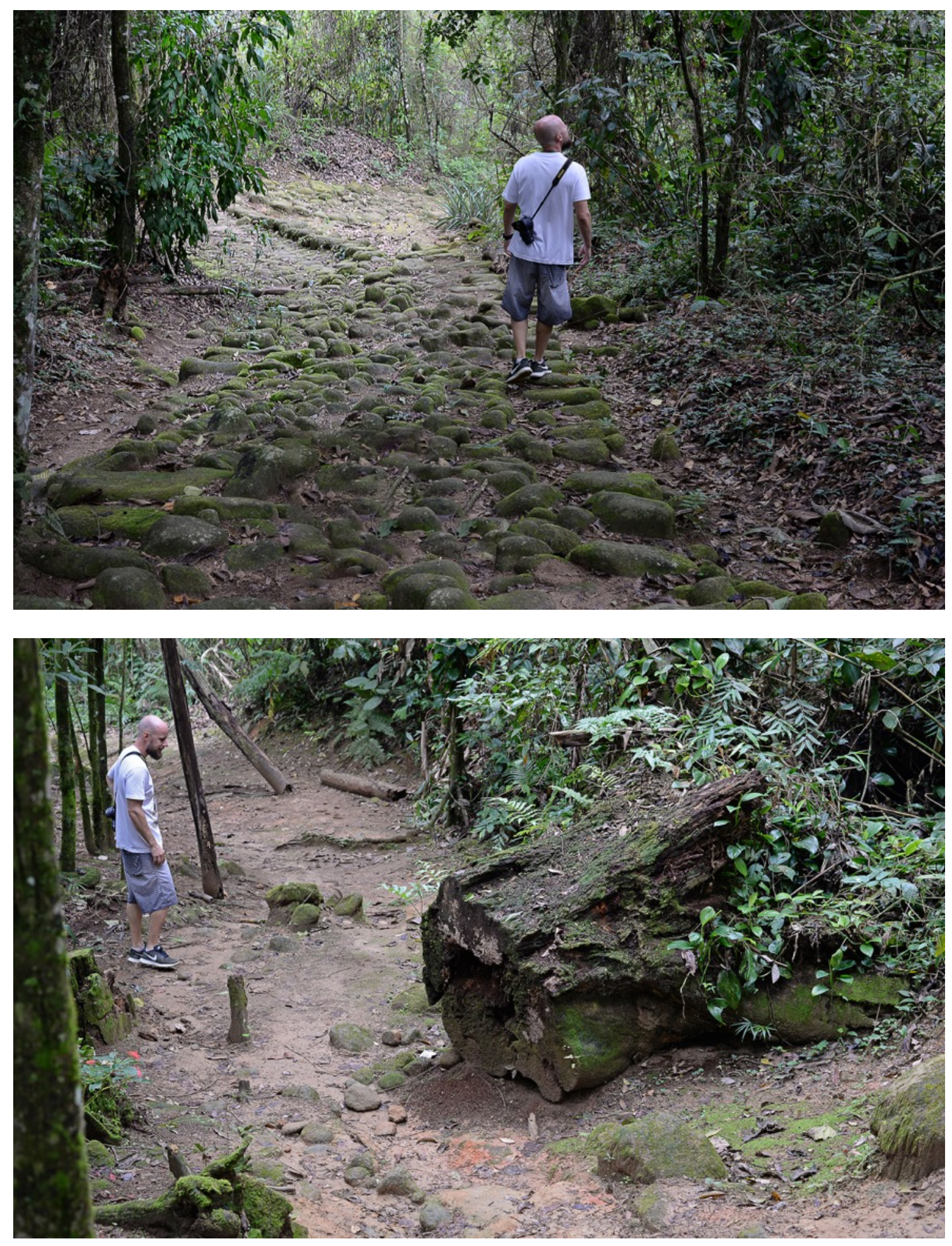

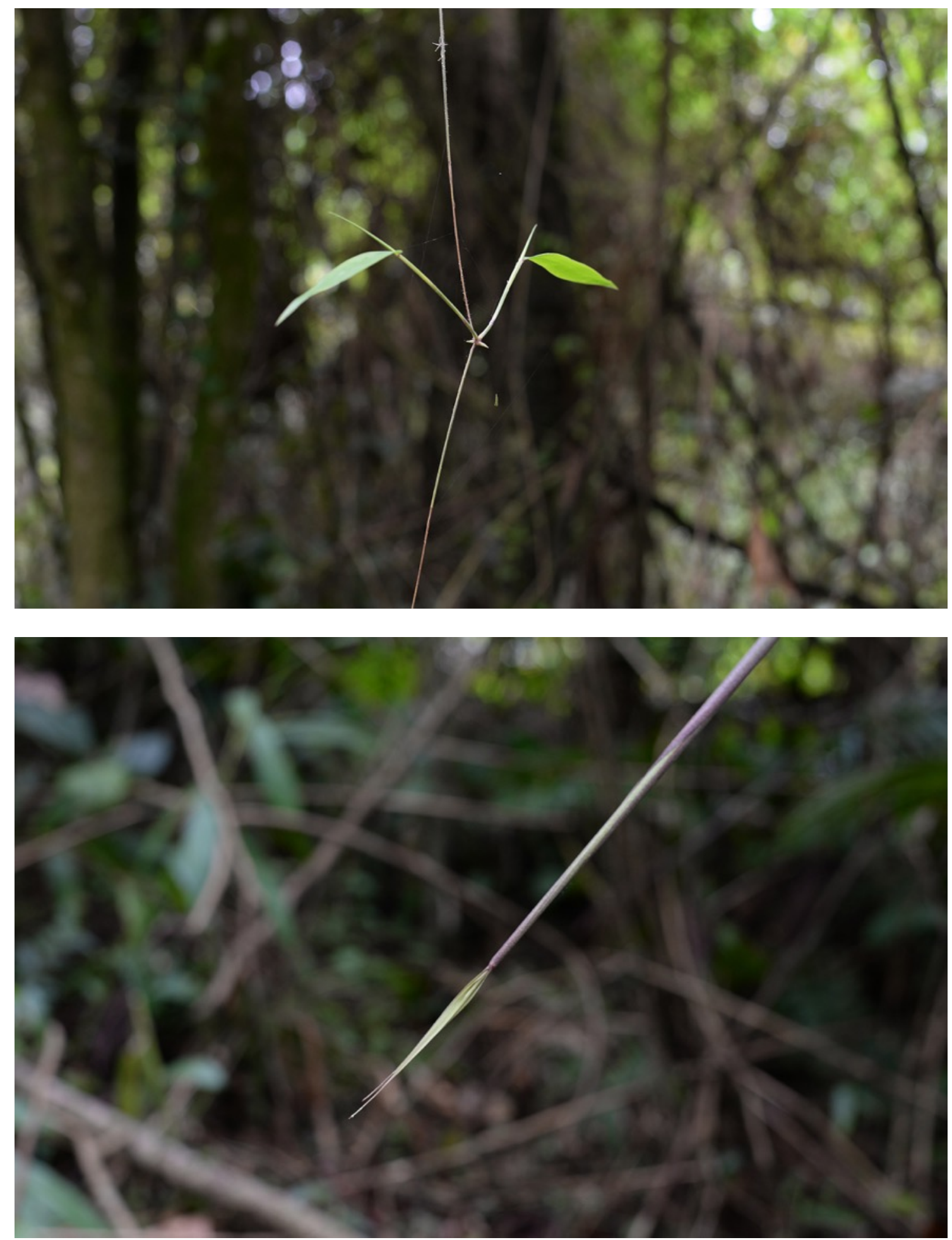

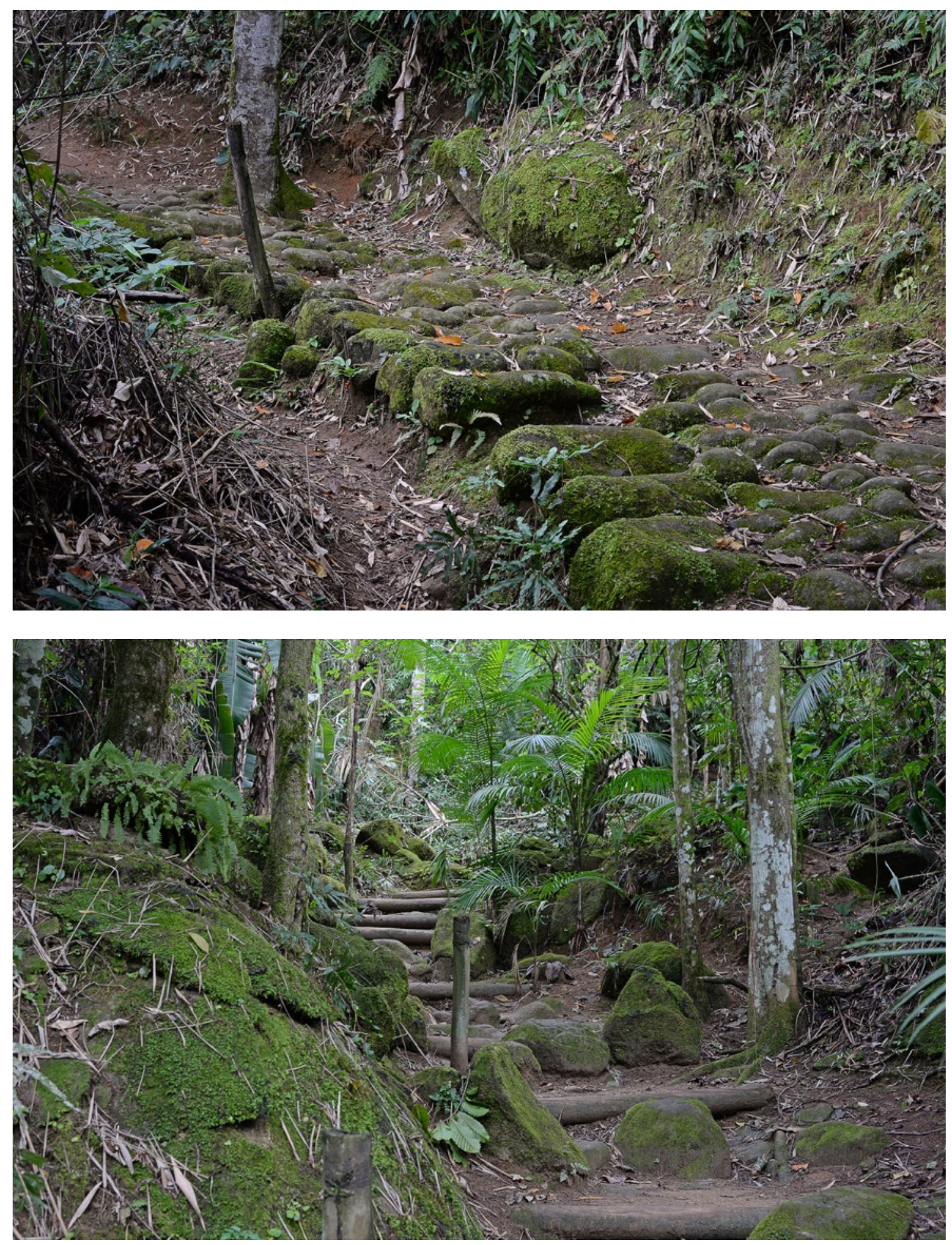

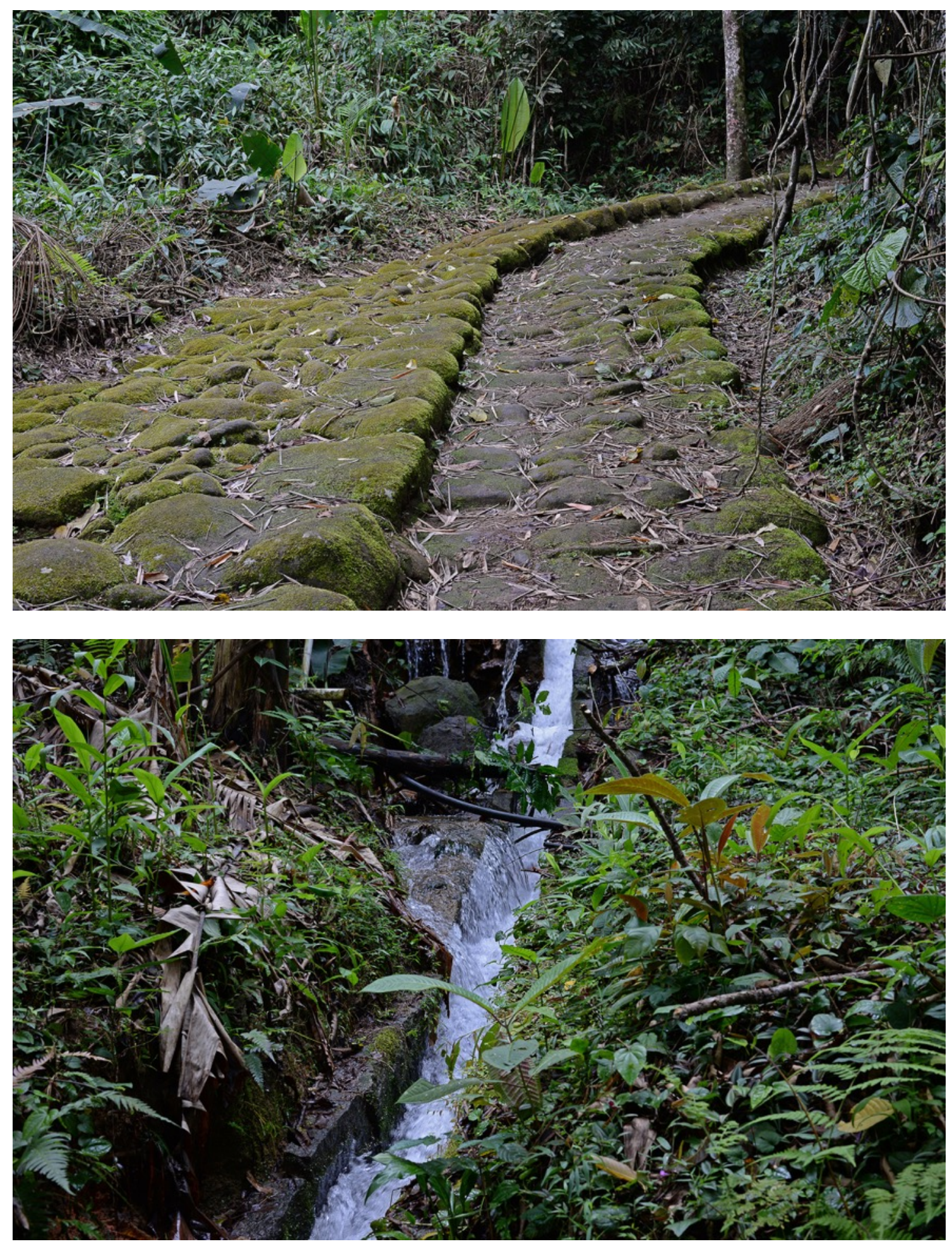

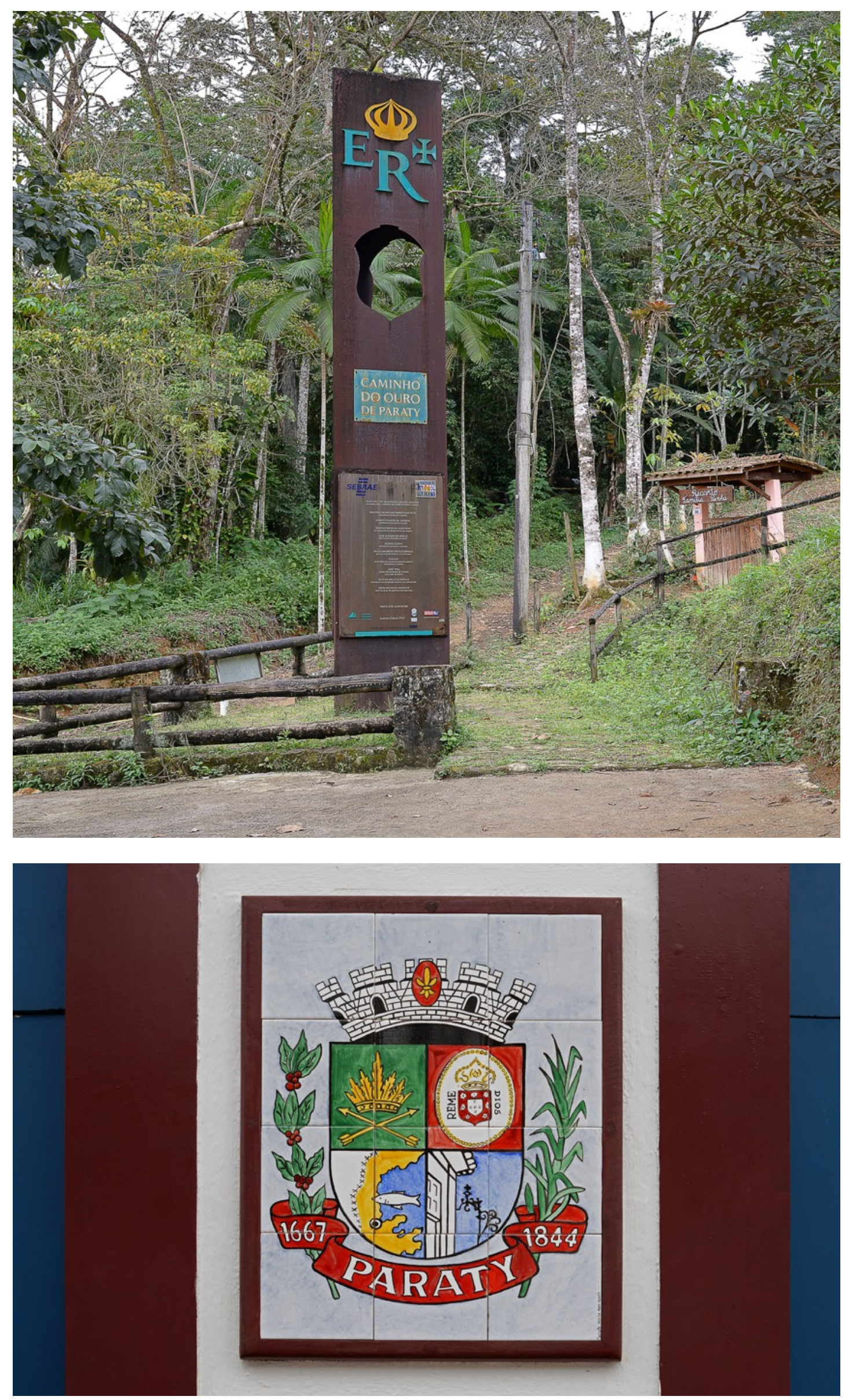


\section{REFERÊNCIAS}

FUNARI, Pedro P. A.; PELEGRINI, Sandra de C. A. Patrimônio histórico e cultural. Rio de Janeiro: Jorge Zahar Ed., 2006.

GURAN, Milton. Linguagem fotográfica e informação. Rio de Janeiro: Rio Fundo Ed., 1992.

LUISI, Emidio. Entrevista. MUSEU DA IMAGEM E DO SOM / INSTITUTO ITALIANO DI CULTURA. Antropologia visual: a fotografia. São Paulo, 1982.

COMISSÃO PERMANENTE PRÓ SÍTIO DO PATRIMÔNIO MUNDIAL DE PARATY. Dossiê: O caminho do ouro em paraty e sua paisagem - a importância do reconhecimento de Paraty como Sítio do Patrimônio Mundial da UNESCO. Prefeitura Municipal de Paraty - Secretaria Executiva de Governo. Paraty / RJ, 11 de setembro de 2007.

RIBAS, Marcos C. A história do caminho do ouro em Paraty. Contest Produções Culturais - Paraty / RJ, 2003.

ROCHA, Ana Luiza C. da; ECKERT, Cornelia. Etnografia de rua: estudo de antropologia urbana. Porto Alegre: UFRGS, 2007.

SILVA, Jardel S. - III SIMPÓSIO NACIONAL DE GEOGRAFIA POLÍTICA Universidade Federal do Rio de Janeiro - jardelsandy@gmail.com - REVISTA GEONORTE, Edição Especial 3, V.7, N.1, p.782-797, 2013. (ISSN - 2237-1419).

SPINI, Sandro. Entrevista. MUSEU DA IMAGEM E DO SOM / INSTITUTO ITALIANO DI CULTURA. Antropologia visual: a fotografia. São Paulo, 1982.

TOLEDO, Gabriel. Entrevista. Paraty / RJ, 2018.

\section{REFERÊNCIAS ONLINE:}

http://www.institutoestradareal.com.br/estradareal - Instituto Estrada Real. Acesso em: 22/11/2019.

http://www.paratyonline.com/jornal/2012/02/confira-a-programacao-do-aniversario-deparaty/ - Acesso em: 22/11/2019.

www.cepa.tur.br/comtursap/PDT\%20Paraty.pdf - Plano Estratégico do Turismo de Paraty 2002 - SEBRAE/RJ. Acesso em: 12/02/2020.

Recebido: $12 / 03 / 2020$

Aprovado: $08 / 12 / 2020$ 